\title{
EFEKTIFITAS PENERAPAN TILANG ELEKTRONIK TERHADAP PELANGGARAN LALU LINTAS DI WILAYAH HUKUM POLDA METRO JAYA
}

\author{
Erik Suriadi Harja ${ }^{1}$, Kristiawanto ${ }^{2}$, Santrawan T. Paparang ${ }^{3}$ \\ $1,2,3$ \\ Magister Hukum, Universitas Jayabaya \\ E-mail: Harjaeriksuriadi@gmail.com
}

\begin{abstract}
Abstrak
Penelitian ini bertujuan untuk mengetahui efektivitas Tilang Elektronik atas pelanggaran lalu lintas di wilayah hukum Polda Metro Jaya. Penelitian berjenis yuridis empiris ini menggunakan pendekatan kasus. Data dikumpulkan dengan tenik penelitian lapangan. Berdasarkan temuan, efektivitas penerapan Tilang elektronik terhadap pelanggaran lalu lintas di wilayah hukum Polda Metro Jaya dinilai belum optimal dalam menanggulangi pelanggaran lalu lintas yang disebabkan oleh kamera ETLE yang dapat mendeteksi jenis pelanggaran tertentu saja. Selain itu, terdapat faktor yang mempengaruhi efektivitas penerapannya, seperti faktor substansi hukum yang belum diatur dalam Peraturan Kapolri, faktor penegak hukum, faktor sarana atau fasilitas, faktor budaya hukum masyarakat, serta faktor alam atau lingkungan.
\end{abstract}

Kata kunci: Penerapan Tilang Elektronik, Pelanggaran Lalu Lintas, Kamera ETLE

\begin{abstract}
For the purpose of this study, the efficiency of Electronic Ticketing for traffic offenses in the metro jaya police jurisdiction is being evaluated. This is an empirical judicial research that takes a caseby-case method. Techniques for collecting data in the field. The results indicate that the efficiency of the deployment of electronic ticketing against traffic offences in the jurisdiction of Polda Metro Jaya in regards of handling traffic offences has not been optimized since the ETLE camera can only recognize specified types of offences. Legal essence, law enforcement, means or facilities, cultural and community law aspects, as well as natural or environmental factors, all have an impact on the success of electronic ticketing.
\end{abstract}

Keywords: Electronic Tickets Implementation, Traffic Offence, ETLE Camera

\section{PENDAHULUAN}

Telah terjadi perubahan dramatis dalam cara kita menjalani hidup karena kemajuan ilmu pengetahuan dan teknologi seperti penemuan kendaraan bermotor. Dahulu masyarakat mengandalkan kuda dan kelengkapan seadanya sebagai alat transportasi darat, namun seiring kemajuan ilmu pengetahuan dan teknologi, kendaraan tradisional pun mulai digantikan. Disisi lain, penggunaan sarana transportasi kendaraan bermotor bagi kehidupan masyrakat ini menimbulkan dampak positif maupun negatif.

Lalu lintas yang macet kini diperparah dengan meningkatnya pelanggaran lalu lintas, namun tidak disertai dengan perluasan jalan. Pelanggaran lalu lintas ialah salah satu dari sekian faktor penyebab terjadinya kecelakaan di jalan raya yang dapat mengakibatkan kematian ataupun luka berat. Selain itu, dapat pula menyebabkan kerugian bagi pengendara 
dan mereka yang terlibat dalam kecelakaan itu, termasuk hilangnya nyawa dan harta benda, yang merupakan sesuatu yang tidak seorang pun ingin menanggungnya.

Setiap tahun semakin banyak orang-orang yang melanggar peraturan lalu lintas, menurut Polda Metro Jaya, terjadi peningkatan dari 1.324.101 jumlah pelanggaran di 2017, menjadi 1.617.565 pelanggaran terjadi di 2018, dan 1.698.270 di tahun 2019. Berdasarkan laporan tahunan Lalu Lintas Polda Metro Jaya tahun 2017-2019, dimana pada tahun 2018 sebanyak 5.903 kasus kecelakan telah terjadi dan hal tersebut meningkat pada 2019 lalu dimana 8.877 kecelakkan telah terjadi.

Oleh karena itu, upaya pemberantasan pelanggaran lalu lintas di jalan raya telah dilakukan dengan cara memberi tilang kepada setiap pengemudi kendaraan bermotor yang melakukan pelanggaran lalu lintas sebagaimana dimaksud dalam Undang-Undang Nomor 22 Tahun 2009 tentang Lalu Lintas dan Angkutan Jalan. Pengemudi kendaraan bermotor yang terkena tilang oleh polisi lalu lintas saat bertugas ataupun selama razia di jalan dapat hadir secara langsung atau diwakilkan di persidangan ataupun membayar denda yang telah ditentukan.

Saat ini tilang kini tidak hanya dilaksanakan oleh polisi lalu lintas di jalan raya, namun kamera CCTV pun kini dapat mendeteksi aktivitas pengendara di jalan raya, sehingga jika pelanggaran lalu lintas terjadi maka CCTV tersebut dapat mengambil foto kendaraan bermotor yang melakukan pelanggaran lalu lintas dan digunakan sebagai barang bukti dalam kasus pelanggaran lalu lintas yang akan dilayangkan di pengadilan, dimana hal ini telah ditentukan dalam Pasal 243 ayat (3) huruf d dan Pasal 272 Undang-Undang Nomor 22 Tahun 2009 tentang Lalu Lintas dan Angkutan Jalan, serta diatur lebih lanjut dalam Pasal 14 ayat (3), Pasal 23 dan Pasal 28 Peraturan Pemerintah Nomor 80 Tahun 2012 tentang Tata Cara Pemeriksaan Kendaraan Bermotor di Jalan dan Penindakan Pelanggaran Lalu Lintas dan Angkutan Jalan.

Dalam hal pelanggaran dalam lalu lintas, penggunaan tilang elektronik dapat membuat penegakan hukum lebih mudah bagi polisi lalu lintas, namun terdapat kekurangan terkait bukti rekaman CCTV pelanggaran, dimana kendaraan yang bersangkutan akan diidentifikasi berdasarkan Nomor Kendaraan Bermotor. Setelah terjadi pelanggaran, surat konfirmasi dikirimkan kepada pemiliknya sesuai dengan data kendaraan bermotor. Hal ini tentu dapat menimbulkan masalah jika kendaraan telah dipindahkan ke pemilik baru, tetapi identitas pemilik sebelumnya belum diperbarui, atau pelat nomor kendaraan telah digunakan yang tidak sesuai dengan hukum.

Dengan menggunakan peralatan elektronik seperti kamera CCTV terhadap pelanggaran lalu lintas di jalan raya, maka perlu untuk mempelajari seberapa efisien tilang elektronik terhadap pelanggaran lalu lintas di wilayah hukum Polda Metro Jaya, sehingga dapat dipahami cara kerja tilang elektronik. Disamping itu, dapat diketahui apakah pelanggaran lalu lintas yang dilakukan oleh pengendara di jalan raya dapat dikurangi melalui penggunaan tilang elektronik, dan Direktorat Lalu Lintas Polda Metro Jaya dapat menggunakan informasi ini sebagai dasar untuk menerapkan tilang elektronik di jalan raya.

\section{TINJAUAN PUSTAKA}

\subsection{Penegakan Hukum}




\section{POLICY, LAW, NOTARY AND REGULATORY ISSUES (POLRI) \\ VOLUME 1 ISSUE 2 (2022)}

Penegakan atau "enforcement" dalam Black law dictionary dinyatakan sebagai "the act of putting something such as a law into effect, the execution of a law". Sedangkan penegak hukum (law enforcement officer) artinya adalah "those whose duty it is to preserve the peace" (Henry, 1998). Lebih lanjut, penegak dijelaskan sebagai yang mendirikan, menegakkan menurut KBBI. Penegak hukum bertanggung jawab untuk menegakkan hukum, yang awalnya hanya mencakup polisi dan jaksa tetapi akhirnya berkembang menjadi pengadilan, pengacara, dan lembaga masyarakat.

Kepolisian, kejaksaan, pengadilan, dan lembaga kemasyarakatan merupakan semua komponen yang dikembangkan oleh negara untuk mewujudkan gagasan hukum yang abstrak tentang keadilan, kepastian, dan kemanfaatan sosial. Terlepas dari kemandirian mereka, tugas dari badan-badan ini adalah sama dimana semuanya bekerja untuk menerapkan konsep-konsep hukum dalam masyarakat (Satjipto, 2009).

Soerjono Soekanto (2007) meyakini bahwa esensi penegakan hukum adalah menyebarluaskan hubungan antara nilai-nilai yang diekspresikan dalam aturan-aturan yang tegas dengan perwujudan dan sikap tindakan sebagai rangkaian nilai-nilai tahap akhir yang dikembangkan untuk menciptakan dan memelihara ketentraman hidup. Inilah yang disebut Soerjono Soekanto sebagai "inti konseptual" dan "makna" penegakan hukum. Sudarto mendefinisikan penegakan hukum sebagai "perhatian dan penegakan", yang meliputi baik perbuatan melawan hukum yang terjadi sekarang (onrecht in actu) maupun perbuatan melawan hukum yang mungkin terjadi di masa yang akan datang (onrecht in potentie) (Atmasasmita, 2011).

Lebih lanjut, Romli Atmasasmita (2011) menyebutkan bahwa dalam penegakan hukum terdapat nilai keadilam yang dapat menopang keseimbangan, keselarasan, dan kerukunan antara kepentingan individu ataupun kepentingan masyarakat. Dengan kata lain, aturan hukum tidak hanya sah (validity) dalam arti memiliki legalitas, tetapi juga harus memiliki nilai (value).

Mengenai unsur-unsur yang mempengaruhi penegakan hukum, Soerjono Soekanto (2007) menyebutkan faktor-faktor berikut, di mana faktor-faktor ini memiliki konotasi netral, oleh karena itu pengaruh baik atau buruk berada dalam aspek-aspek ini, aspek tersebut yaitu:

1. Faktor hukumnya sendiri (undang-undang);

2. Faktor penegak hukum;

3. Faktor sarana atau fasilitas yang mendukung penegakan hukum;

4. Faktor masyarakat; dan

5. Faktorkebudayaan.

\subsection{Pelanggaran Lalu Lintas}

Pasal 1 Undang-Undang Nomor 22 Tahun 2009 tentang Lalu Lintas dan Angkutan Jalan mendefinisikan lalu lintas sebagai suatu sistem yang terdiri dari kendaraan, pengemudi, pengguna jalan, dan pelaksanaannya. Demikian pula dalam Pasal 1 angka 2, lalu lintas dipahami sebagai pergerakan kendaraan dan orang-orang di jalan. Dalam Pasal 1 angka 3 mendefinisikan angkutan jalan sebagai perpindahan orang atau benda dengan kendaraan dalam ruang lalu lintas jalan.

Selain itu, pelanggaran merupakan bagian dari tindak pidana yang didefinisikan sebagai kejahatan oleh hukum pidana. Mala in se adalah perbuatan yang dianggap tidak adil karena 
melanggar aturan sosial sebelum ditetapkan sebagai kejahatan oleh hukum, sedangkan mala prohibitia yaitu perbuatan yang ditetapkan oleh undang-undang sebagai kejahatan atau pelangaran (Hiariej, 2014).

Dalam kejahatan (rechtdelicten) terdapat aspek yang menunjukkan tercelanya tidak hanya termasuk dalam hukum, namun juga terdapat dalam masyarakat. Sementara, sifat tercela dari suatu perlanggaran (wetsdelicten) berasal dari keberadaannya sebagai perbuatan yang dilarang dalam undang-undang (Chazawi, 2002). Disamping itu, berdasarkan kriteria lainnya bahwa suatu kejahatan adalah kejahatan yang melanggar hak-hak hukum yang dapat membahayakan secara nyata, sedangkan pelanggaran itu adalah delik yang hanya berbahaya secara in abstracto hanya apabila perbuatan itu tertuang dalam undang-undang (Andi Hamzah, 2012).

Pelanggaran lalu lintas dianggap sebagai tindakan yang dilakukan oleh setiap orang yang terlibat dalam lalu lintas dan angkutan jalan, yang bertentangan dengan peraturan perundang-undangan lalu lintas yang ada, sebagaimana dimaksud dalam Pasal 274 sampai dengan 309, dan 313 Undang-Undang Nomor 22 Tahun 2009 tentang Lalu Lintas dan Angkutan Jalan.

\subsection{Pengertian dan Tugas Polri di Bidang Lalu Lintas}

Istilah "polisi" mengacu pada segala sesuatu yang ada hubungannya dengan kepolisian dan lembaga-lembaga yang mendukungnya, seperti yang didefinisikan oleh Pasal 1 angka 1 UU No. 2 Tahun 2002 tentang Polri. Tugas pokok Polri meliputi: memelihara kemanan dan ketertiban masyarakat, menegakkan hukum dan memberikan perlindungan, pengayoman dan pelayanan kepada masyarakat sebagaimana diatur dalam Pasal 13. Sedangkan tugas pokok dalam lalu lintas diatur dalam Pasal 14 ayat (a) huruf b Undang-Undang Nomor 2 Tahun 2002. Berdasarkan Pasal 15 ayat (2) huruf b dan d, dijelaskan bahwa "Polri sesuai peraturan perundang-undangan lainnya berwenang menyelenggarakan registrasi dan identifikasi kendaraan bermotor, serta memberikan surat izin mengemudi kendaraan bermotor".

Secara khusus Undang-Undang Nomor 22 Tahun 2009 tentang Lalu Lintas dan Angkutan Jalan memberi wewenang kepada Polri untuk menegakan hukum pelanggaran beserta penyidikan tindak pidana lalu lintas, dimana hal tersebut tertuang dalam Pasal 260 sebagai berikut:

1. Dalam hal penindakan pelanggaran dan penyidikan tindak pidana, Penyidik Polri selain yang diatur di dalam Kitab Undang-Undang Hukum Acara Pidana dan undang-undang tentang Polri, di bidang lalu lintas dan angkutan jalan memiliki kewenangan tertentu (Tabel 1).

2. Pelaksanaan penindakan pelanggaran dan penyidikan tindak pidana sebagaimana dimaksud pada ayat (1) dilakukan sesuai dengan ketentuan peraturan perundangundangan.

Tabel 1 Kewenangan Polri dalam lalu lintas dan angkutan jalan 


\begin{tabular}{l}
\hline Kewenangan \\
a. Memberhentikan, melarang, atau menunda pengoperasian dan menyita sementara kendaraan bermotor \\
yang patut diduga melanggar peraturan berlalu lintas atau merupakan alat dan/atau hasil kejahatan; \\
b. Melakukan pemeriksaan atas kebenaran keterangan berkaitan dengan penyidikan tindak pidana di \\
bidang lalu lintas dan angkutan jalan; \\
c. Meminta keterangan dari pengemudi, pemilik kendaraan bermotor, dan/atau perusahaan angkutan \\
umum; \\
Melakukan penyitaan terhadap Surat Izin Mengemudi, kendaraan bermotor, muatan, Surat Tanda Nomor \\
e. Mendaraan Bermotor, Surat Tanda Coba Kendaraan Bermotor, dan/atau tanda lulus uji sebagai barang \\
f. Meraturanperundang-undangan; \\
g. Menghentikan penyidikanjika tidak terdapat cukup bukti; \\
h. Melakukanpenahananyang berkaitandengantindak pidanakejahatanlalu lintas; dan/atau \\
i. Melakukan tindakan lain menurut hukum secara bertanggung jawab.
\end{tabular}

\subsection{Pengertian dan Dasar Hukum Tilang Elektronik}

Dalam UU No. 22 Tahun 2009 tentang Lalu Lintas dan Angkutan Jalan tidak dijelaskan istilah "tilang atau bukti pelanggaran". Orang yang mendapatkan tilang pelanggaran lalu lintas dan angkutan jalan harus menunjukkan bukti pelanggaran tertentu dalam format tertentu. Demikian disampaikan pemerintah dalam Pasal 1 angka 4 Peraturan Pemerintah Nomor 80 Tahun 2012 tentang Tata Cara Pemeriksaan Kendaraan Bermotor di Jalan dan Penanganan Pelanggaran Lalu Lintas dan Angkutan Jalan. Menurut Karjadi (2011) Tilang atau bukti lain pelanggaran lalu lintas adalah berfungsi sebagai undangan bagi pelanggar lalu lintas untuk menghadiri siding di pengadilan, sekaligus tanda polisi telah menyita barang dari pelanggar lalu lintas.

Sementara itu, Tilang elektronik pada Pasal 243 ayat (3) huruf d Undang-Undang Nomor 22 Tahun 2009 tentang Lalu Lintas dan Angkutan Jalan, secara implisit dinyatakan bahwa penegakan hukum dengan alat elektroknik digunakan dalam kegiatan pusat kendali sistem informasi dan komunikasi lalu lintas dan angkutan jalan. Pasal 272 peralatan elektronik dapat digunakan, dimana hasil penggunaan peralatan elektronik tersebut dapat digunakan sebagai alat bukti dipengadilan.

Menurut Peraturan Pemerintah Nomor 80 Tahun 2012 tentang Tata Cara Pemeriksaan Kendaraan Bermotor di Jalan dan Penindakan Pelanggaran Lalu Lintas dan Angkutan Jalan, Pasal 14 ayat (3) di sebutkan bahwa "pemeriksaan secara insindetil karena tertangkap tangan dilakukan pada saat terjadi pelanggaran yang terlihat secara kasat mata atau tertangkap oleh alat penegakan hukum secara elektronik". Demikian dengan Pasal 23, bahwa "penindakan pelanggaran lalu lintas dan angkutan jalan didasarkan pada hasil temuan dalam proses pemeriksaan kendaraan bermotor, laporan dan rekaman peralatan elektronik".

Kemudian dalam Pasal 28 Pemerintah Nomor 80 Tahun 2012 tentang Tata Cara Pemeriksaan Kendaraan Bermotor di Jalan dan Penindakan Pelanggaran Lalu Lintas dan 
Angkutan Jalan, dijelaskan bahwa "penindakan terhadap pelanggaran lalu lintas dan angkutan jalan yang didasarkan atas hasil rekaman peralatan elektronik merupakan dasar bagi Petugas Polri atau PPNS di bidang lalu lintas untuk menerbitkan surat Tilang yang harus dilampiri dengan bukti rekaman alat penegakan hukum elektronik, dimana surat Tilang tersebut disampaikan kepada pelanggar sebagai pemberitahuan dan panggilan untuk hadir dalam sidang pengadilan".

Tilang elektronik secara implisit dijelaskan dalam Peraturan Kapolri Nomor 5 Tahun 2012 tentang Registrasi dan Identifikasi Kendaraan Bermotor, Pasal 115 ayat (3) bahwa "pemblokiran STNK dilakukan untuk kepentingan pencegahan pengesahan atau perpanjangan regident kendaraan bermotor dan penegakan hukum pelanggaran lalu lintas," dan dijelaskan pula dalam Ayat (5) bahwa "permintaan pemblokiran STNK untuk kepentingan yang dimaksud pada ayat (3) diajukan oleh penegak hukum terhadap kendaraan bermotor yang diduga terlibat kecelakaan lalu lintas dan melarikan diri, atau kendaraan bermotor yang berdasarkan data elektronik telah melakukan pelanggaran lalu lintas".

\section{METODE PENELITIAN}

Penulisan artikel ini yaitu dengan menggunakan pendekatan kasus dan oleh karena itu penelitian ini merupakan penelitian yuridis empiris (Marzuki, 2013). Penelitian lapang (field research) dipergunakan dalam mengumpulkan data primer, yaitu dengan menggunakan prosedur wawancara untuk mengumpulkan informasi tentang pikiran, perasaan, sikap, perilaku, dan aspek lain dari suatu masalah atau masalah hukum yang diselidiki (Soekanto, 2007b). Kemudian data dianalisis secra yuridis-kualitatif atau menelaah hasil penelitian, khususnya data primer yang dikumpulkan langsung dari lapangan untuk memperjelas topik yang diteliti (Ash-Shofa, 2004).

\section{HASIL DAN PEMBAHASAN}

\subsection{Efektivitas Tilang Elektronik}

Upaya dalam menindak pelanggaran lalu lintas di wilayah Polda Metro Jaya telah dilakukan dengan menerapkan sistem "Electronic Traffic Law Enforcement (ETLE)" adalah sistem penegakan lalu lintas yang menggunakan perangkat elektronik seperti kamera untuk mengidentifikasi berbagai bentuk pelanggaran lalu lintas dan secara otomatis memberikan data kendaraan atau dikenal dengan "Automatic Number Plate Recognition". Kamera EPolice dapat mengidentifikasi segala bentuk pelanggaran marka jalan dan lampu lalu lintas, sementara kamera Check Point dapat mendeteksi pelanggaran plat ganjil genap, pengendara yang tidak mengenakan sabuk pengaman, dan penggunaan gadget oleh pengemudi kendaraan.

Pada tahun 2019 lalu, telah ditempatkan kamera E-Police dengan sistem ETLE yang dapat mendeteksi kendaraan bermotor yang melanggar ketentuan lalu lintas, kamera EPolice ini berjumlah 4 buah dan 8 buah kamera Check Point di Jalan Merdeka Selatan (traffic light Patung Kuda), Jalan Gajah Mada (traffic light Gajah Mada Plaza), traffic light Sarinah arah ke Bundaran Hotel Indonesia, dan traffic light Sarinah arah ke Monumen Nasional. Sedangkan kamera Check Point ditempatkan di Jembatan Penyeberangan Orang Kementerian Pariwisata, Jalan Medan Merdeka Selatan (traffic light Patung Kuda), traffic light 


\section{POLICY, LAW, NOTARY AND REGULATORY ISSUES (POLRI) VOLUME 1 ISSUE 2 (2022)}

Sarinah arah ke Bundaran Hotel Indonesia, dibawah Jalan Layang Non Tol arah ke Semanggi, di bawah Jalan Layang Non Tol arah ke Bundaran Hotel Indonesia, Jembatan Penyeberangan Orang Kementerian PAN RB, Jembatan Penyeberangan Orang Ratu Plaza, Jembatan Penyeberangan Orang Hotel Sultan.

Adapun beberaapa pelanggaran yang di deteksi dalam kamera ETLE seperti pengemudi yang melanggar aturan Alat Pemberi Isyarat Lalu Lintas (APIL) dan lampu lalu lintas (traffic light), melannggar aturan atas marka jalan dan aturan mengenai ganjil genap dimana hal ini tertera dalam Undang- Undang Nomor 22 Tahun 2009 tentang Lalu Lintas dan Angkutan Jalan, yaitu Pasal 287 ayat(1). Selain itu, terdapat juga pelanggaran atas Pasal 283 tentang "pelanggaran menggunakan ponsel saat berkendara", Pasal 287 ayat (5) tentang "pelanggaran terhadap batas kecepatan", Pasal 291 tentang "pelanggaran tidak penggunaan helm bagi pengemudi sepeda motor" dan Pasal 300 tentang "pelanggaran menggunakan jalur khusus Busway".

Dalam hal mekanisme atau prosedur penerapan Electronic Traffic Law Enforcement (ETLE) telah dinyatakan dalam Keputusan Kapolda Metro Jaya Nomor: Kep/671/VIII/2019 tanggal 29 Agustus 2019 tentang Standar Operasional Prosedur Electronic Traffic Law Enforcement (ETLE) yaitu sebagai berikut:

Tabel 2 Standar Operasional Prosedur Electronic Traffic Law Enforcement (ETLE)

\begin{tabular}{|c|c|c|}
\hline No & Tahapan & Prosedur \\
\hline 1 & Analisa dan verifikasi & $\begin{array}{l}\text { Analisa hasil rekaman kamera ETLE apakah merupakan pelanggaran lalu } \\
\text { lintas atau bukan dan verifikasi data kendaraan bermotor dengan database } \\
\text { pada Electronic Registration Identification (ERI); }\end{array}$ \\
\hline 2 & $\begin{array}{l}\text { Pembuatan dan } \\
\text { pengiriman surat } \\
\text { konfirmasi }\end{array}$ & $\begin{array}{l}\text { Pembuatan surat konfirmasi sesuai dengan data hasil analisa dan verikasi } \\
\text { kemudian dikirimkan ke alamat pemilik kendaraan atau pelanggar lalu } \\
\text { lintas melalui jasa pengiriman atau media elektronik seperti email, SMS } \\
\text { atau aplikasi messenger; }\end{array}$ \\
\hline 3 & Konfirmasi & $\begin{array}{l}\text { Konfirmasi yang dilakukan oleh pemilik kendaraan bermotor atau } \\
\text { pelanggar lalu lintas setelah menerima surat konfirmasi yang dilakukan } \\
\text { dengan cara mengirim kembali surat konfirmasi atau mendatangi } \\
\text { langsung Posko ETLE Subdit Gakkum Ditlantas Polda Metro Jaya atau } \\
\text { melakukan konfrimasi secara digital melalui alamat website https://etle- } \\
\text { pmj.info sesuai dengan nomor referensi dalam surat konfirmasi; }\end{array}$ \\
\hline 4 & Penindakan & $\begin{array}{l}\text { Pemberian sanksi Tilang kepada pemilik kendaraan bermotor atau } \\
\text { pelanggar lalu lintas yang telah melakukan konfirmasi yang disertai } \\
\text { dengan pengiriman kode Briva ke nomor handphone pemilik atau } \\
\text { pelanggar lalu lintas tersebut; }\end{array}$ \\
\hline 5 & $\begin{array}{l}\text { Pembayaran denda } \\
\text { tilang }\end{array}$ & $\begin{array}{l}\text { Pembayaran dengan Tilang oleh pemilik kendaraan bermotor atau } \\
\text { pelanggar lalu lintas setelah menerima kode Briva yang dilakukan melalui } \\
\text { M-Banking, ATM atau Teller Bank BRI; }\end{array}$ \\
\hline 6 & Pengajuan blokir & $\begin{array}{l}\text { Permohonan blokir STNK oleh Petugas ETLE ke Samsat sesuai domisili } \\
\text { kendaraan bermotor apabila pemilik kendaraan bermotor atau pelanggar } \\
\text { lalu lintas tidak melakukan konfirmasi dalam jangka waktu paling lama } 5 \\
\text { (lima) hari kerja atau tidak melakukan pembayaran denda tilang dalam } \\
\text { jangka waktu paling lama } 7 \text { (tujuh) hari kerja; }\end{array}$ \\
\hline 7 & Buka blokir & $\begin{array}{l}\text { Permohonan blokir STNK oleh Petugas ETLE ke Samsat sesuai domisili } \\
\text { kendaraan bermotor apabila pemilik kendaraan bermotor atau pelanggar } \\
\text { lalu lintas tidak melakukan konfirmasi dalam jangka waktu paling lama } 5 \\
\text { (lima) hari kerja atau tidak melakukan pembayaran denda tilang dalam } \\
\text { jangka waktu paling lama } 7 \text { (tujuh) hari kerja; }\end{array}$ \\
\hline
\end{tabular}

Mengenai hal ini, berdasarkan Laporan Anev ETLE Subditgakkum Ditlantas Polda 
Metro Jaya Tahun 2019 bahwa Petugas ETLE Subditgakkum Ditlantas Polda Metro Jaya telah menindak pengemudi yang melanggar ketentuan sejak bulan November 2018 Desember 2019 dimana rincian jenis dan jumlah pelanggarannya dapat dilihat pada tabel berikut.

Tabel 3 Jenis dan jumlah pelanggaran yang terjadi

\begin{tabular}{ll}
\hline Jenis Pelanggaran & Jumlah Pelanggaran \\
\hline Ketentuan Ganjil Genap & 6.726 \\
Ketentuan Penggunaan Sabuk Pengaman & 23.427 \\
Ketentuan Penggunaan Handphone & 1.435 \\
Ketentuan Traffic Light Atau Marka Jalan & 33.166 \\
\hline Pelanggaran yang ditindaklanjuti & Jumlah Pelanggar \\
\hline Melakukan konfirmasi ke Posko ETLE & 15.923 \\
Melakukan konfirmasi melalui website & 16.179 \\
Membayar denda Tilang melalui Bank BRI & 8.990 \\
Membayar denda Tilang di Kejaksaan & 4.269 \\
Pelanggar yang telah dikirim ke Pengadilan dan telah mendapatkan Putusan & 28.718 \\
\hline
\end{tabular}

Demikian apabila terdapat pelanggar yang sama sekali tidak menyelesaikan prosedur tersebut, maka pemblokiran STNK kendaraan akan dilakukan, dimana rincian tersebut dapat dilihat di tabel berikut.

Tabel 4 Rincian penyelesaian

\begin{tabular}{ll}
\hline Rincian penyelesaian & Jumlah Unit \\
\hline Nopol yang terblokir & 23.610 \\
Nopol yang tidak terblokir & 272 \\
Permohonan buka blokir & 4.677 \\
Nopol yang tidak ditemukan & 1.200 \\
Kendaraan yang melakukan pelanggaran kembali & 64.98 \\
\hline
\end{tabular}

Bersumber dari hasil penerapan Tilang elektronik dengan system ETLE diatas, maka dapat ditarik kesimpulan jika pelanggaran dalam wilayah hukum Polda Mtero Jaya menggunakan sistem ETLE dinilai belum optimal, hal ini dikarenakan sistem ETLE hanya bisa menangkap pelanggaran tertentu saja seperti ketentuan: ganjil genap, penggunaan sabuk pengaman, penggunaan gadget, dan pelanggaran atas marka jalan. Di samping itu, karena kebijakan tilang elektronik secara khusus tercantum pada Kcputusan Kapolda Metro Jaya saja, sebagai hasilnya sistem ini belum bisa menindak penilangan dan pemblokiran STNK yang asalnya dari luar wilayah hukum Polda Metro Jaya.

Selanjutnya, dalam mengimplementasikan tilang secara elektronik ini tidak bisa diterapkan bagi pengemudi ataupun pemilik kendaran bermotor jika tidak melakukan konfirmasi pelanggaran yang dideteksi oleh kamera ETLE dimana penyelesaian bisa dilakukan dengan dating ke Posko ETLE langsung atau bisa dilakukan sccara online yang nantinya akan ditentukan apakah dikenakan sanksi tilang dan denda tilang sesuai ketetapan yang telah diatur sebelumnya pada UU No. 22 tahun 2009 mengenai Lalu lintas dan 


\section{POLICY, LAW, NOTARY AND REGULATORY ISSUES (POLRI) \\ VOLUME 1 ISSUE 2 (2022)}

Angkutan Jalan. Namun, terdapat pula kekurangan dalam menindak pelanggaran yang dilakukan oleh kendaraan yang tidak memiliki nomor registrasi yang sama dengan data Samsat yang menyebabkan penindakan tidak dapat dilakukan secara lebih lanjut.

\subsection{Tilang Elektronik yang terkendala beberapa faktor 4.2.1. Faktor Substansi Hukum}

Substansi hukum perundang-undangan terkait (ius constitutum) yang terkait dengan tiket elektronik adalah unsur yang berasal dari peraturan perundang-undangannya sendiri yang merupakan substansi hukum. Tilang secara elektronik tertera dalam UU No. 22 Tahun 2009 tentang Lalu Lintas dan Angkutan Jalan yang mengatur tentang tilang elektronik, yang diatur dalam Pasal 243 ayat (3) dan Pasal 272 yang hanya mengatur tentang alat elektronik sebagai alat bukti di pengadilan, namun tidak membahas mekanisme aplikasi tilang sccara elektronik dalam pelanggaran yang terjadi dilalu lintas.

Adapun peraturan yang diterbitkan pemerintah Nomor 80 Tahun 2012 mengena "Tata Cara Pemeriksaan Kendaraan Bermotor di Jalan dan Penindakan Pelanggaran Lalu Lintas dan Angkutan Jalan", dimana penggunaan alat bukti elektronik dalam bentuk rekaman yang nantinya dijadikan alat bukti sebagai penegakan hukum di persidangan hanya dijelaskan secara implisit dalam Pasal 14 ayat (3), Pasal 23 dan Pasal 28. Atas hal tersebut, maka bisa dikatakan bahwa pengaturan atas prosedur ataupun mekanisme implementasi Tilang secara elektronik belum diatur secara nyata atas penggunaannya terkait pelanggaran yang terjadi di jalan raya.

Namun, saat ini sistem Tilang secara elektronik baru terdapat di Keputusan Kapolda Metro Jaya Nomor: KEP/671/VIII/2019 tanggal 29 Agustus 2019 tentang Standar Operasional Prosedur Electronic Traffic Law Enforcement (ETLE) dimana dalam Peraturan Kapolri belum tertera. Dalam keputusan tersebut mengatur terkait penegakan hukum dengan sistem ETLE yang hanya mengatur di wilayah hukum Polda Metro Jaya. Oleh karena itu, hal ini menyebabkan tidak dapat dilakukannya penindakan bagi pelanggar yang brasal dari luar wilayah hukum Polda Metro Jaya karena tidak ada dasar hukum yang mengaturnya. Menanggapi hal ini, Petugas ETLE Polda Metro Jaya hanya dapat melaporkan pelanggaran lalu lintas tersebut kepada Korlantas Polri guna penindakan lebih lanjut.

\subsubsection{Faktor Penegak Hukum}

Faktor yang berkaitan dengan aparat penegak hukum yang menjalankan peraturan perundang-undangan yang berlaku, dalam hal ini anggota lalu lintas yang melaksanakan tugas penegakan hukum terhadap pelanggaran lalu lintas dari tahap awal terjadinya pelanggaran lalu lintas atas diterapkannya ETLE, ke tahap konfirmasi, tahap penindakan/pemberian tilang, dan terakhir penyelesaian pelanggaran dengan membayarkan denda tilang pada jangka waktu yang ditentukan yang bisa dibayarkan lewat Bank BRI atau kantor Kejaksaan, hal ini tentunya sesuai dengan UU No. 22 Tahun 2009.

Dalam pelaksanaan menegakan hukum atas sistem Electronic Traffic Law Enforcement (ETLE) dibentuk satgas ETLE sesuai Surat Perintah Kapolda Metro Jaya Nomor: Sprin/1856/IX/OPS.4.5/2019 tanggal 11 September 2019. Satgas tersebut yaitu, Petugas Back office (Petugas analisis \& verifikasi dan Petugas penanggungjawab surat konfirmasi), Petugas Posko ETLE (Petugas Tilang, Admin, dan Yanduan), dan terakhir 
yakni Petugas Samsat, dimana tugas dan tangggung jawab yang dilakukan oleh anggota Ditlantas yang bertugas pada Subdit Gakkum dan Subdit Regident bagi anggota yang ditugaskan untuk menangani Electronic Traffic Law Enforcement tersebut merangkap dengan jabatan yang juga diembannya. Hal ini dikarenakan belum ada unit khusus pada Ditlantas Polda Metro Jaya yang secara khusus bertugas dalam Electronic Traffic Law Enforcement, alhasil pelaksanaan tugas belum optimal karena tugas rangkap tersebut.

\subsubsection{Faktor Sarana atau Fasilitas}

Dalam faktor yang melibatkan sarana dan fasilitas ialah pendukung pelaksaanan atas tugas anggota Ditlantas Polda Metro Jaya yang bertujuan menegakkan hukum dalam sistem Tilang secara elektronik bagi pengemudi yang melanggar aturan lalu lintas lewat Electronic Traffic Law Enforcement. Oleh karena itu, sarana seperti kamera E-Police yaitu perangkat kamera yang digunakan guna menangkap pelanggaran marka jalan, kamera Check poin yaitu perangkat kamera yang bisa menangkap pelanggaran yang melanggar aturan ganjil genap, pengunaan sabuk pengaman dan juga gadget bagi pengemudi mobil, atau juga bisa menangkap pelanggaran pelanggaran yang dilakukan oleh pengemudi motor yang tidak mengenakan helm, menerobos jalur buss ataupun kecepatan yang dilanggar. Maka dapat dikatakan bahwa penindakan pelanggaran diluar ketentuan UU No. 22 tahun 2009 tidak bisa dilakukan karena kamera ETLE tidak bisa mendeteksinya.

Selain itu, komputer, server ETLE, aplikasi ETLE, Database Electronic Registration and Identification (ERI), printer, jaringan internet, aplikasi E-Tilang, kode Briva, blanko Tilang, alat tulis kantor serta peralatan komputer juga digunakan dalam menunjang penerapaan sistem ETLE. Dalam hal fasilitas, Back office dan Posko ETLE Subditgakkum digunakan sebagai fasilitas pendukung. Terdapat pula faktor lain seperti anggaran yang belum ada secara khusus guna melaksanakan sistem Electronic Traffic Law Enforcement yang berarti masih mengandalkan dana oprasional serta dana rutin Ditlantas Polda Metro Jaya.

\subsubsection{Faktor Budaya Hukum Masyarakat}

Jika ketentuan mengenai tilang elektronik terhadap pelanggaran lalu lintas diterapkan dalam kasus ini, maka faktor budaya hukum masyarakat merupakan faktor yang berkaitan dengan kondisi lingkungan masyarakat tempat penerapannya. Dalam hal ini faktor tersebut berkaitan dengan kondisi masyarakat sebagai pengendara kendaraan bermotor yang berada di bawah wilayah hukum Polda Metro Jaya.

Masyarakat sering tidak melakukan balik nama atas Bukti Tanda Kepemilikan Kendaraan Bermotor (BPKB) dan Surat Tanda Nomor Kendaraan (STNK) setelah proses jual-beli kendaraan bermotor. Hal ini tentu menjadi masalah apabila terjadi pelanggaran yang mana surat konfirmasi akan ditujukan pada pemilik kendaaraan yang tertera dalam Database Electronic Registration and Identification (ERI). Disamping itu, terdapat penggunaan Tanda Nomor Kendaraan Bermotor (TNKB) yang bebeda dengan nomor registrasi kendaraan yang menyebabkan penindakan tidak dapat ditindak lanjuti. Faktor lainya yakni kebersediaan masyarakat untuk melakukan tindaklanjut atas pelanggarannya yang dapat dilakukan secara langsung ke Posko ETLE atau lewat website yang nantinya jika diselesaikan akan dilanjut pada tahap pemberian sanksi tilang.

\subsubsection{Faktor Alam atau Lingkungan}

Dalam faktor alam, kondisi atas cuaca tempat kamera ETLE beroperasi dapat 


\section{POLICY, LAW, NOTARY AND REGULATORY ISSUES (POLRI) \\ VOLUME 1 ISSUE 2 (2022)}

berpengaruh dalam kinerjanya. Apabila cuaca hujan dengan instensitas tinggi, maka kamera tidak bisa menangkap pelanggaran yan terjadi di jalan raya. Belum lagi kondisi lain jika terjadi sambaran petir, intalasi atau jaringan yang tergenangi air hujan sehingga perangkat kamera korsleting, atau saat server sedang down yang disebabkan gangguan alam lainya menyebabkan kamera tidak terkoneksi.

Faktor lingkungan yakni situasi kamera ETLE beroperasi atau ditempatkan. Kamera ETLE dapat rusak apabila misalnya terdapat tindakan penrusakan sarana oleh massa pengunjuk rasa atau oknum tertentu. Kerusakan yang terjadi tersebut tentu menyebabkan kamera tidak lagi berfungsi dengan normal, yang pada akhirnya tidak bisa lagi mendeteksi pelanggaran.

\section{KESIMPULAN}

Tilang secara elektronik yang dilakukan di wilayah hukum Polres Metro Jaya dinilai belum optimal dalam hal efektivitasnya menindak pelanggaran yang terjadi. Hal ini ditunjukkan dalam indikasi bahwa kamera ETLE tidak dapat mengenali pelangggaran diluar ketentuan UU No. 22 Tahun 2009. Penindakan penegakan hukum juga tidak bisa dilakukan lebih lanjut apabila kendaraan berasal dari Polda lain selain Polda Metro Jaya atau terdapat Tanda Nomor Kendaraan Bermotor yang berbeda dengan nomor registrasi kendaraan bermotor yang tercatat di Samsat. Selain itu, apabila tahapan pelangaran lalu lintas tidak dijalankan oleh pemilik, maka tilang secara elektronik tidak dapat dilaksanakan.

Efektivitas tilang elektronik di wilayah hukum Polda Metro Jaya dipengaruhi atas beberapa faktor. Dalam faktor substansi hukum, belum ada aturan khusus atas Tilang elektronik dimana hanya dalam Keputusan Kapolda Metro Jaya. Dalam faktor penegak hukum, akibat tidak adanya unit khusus yang bertugas maka penanganan Tilang elektronik masih dirangkap oleh anggota Subdit Gakkum Direktorat Lalu Lintas Polda Metro Jaya. Dalam faktor sarana \& fasilitas, fitur kamera ETLE belum mendukung penuh atas segala jenis pelanggaran. Dalam faktor budaya hukum, kurangnya kesadaran masyaarakat atas balik nama bukti kepemilikan kendaraan bermotor dan juga pengunaan tanda nomor kendaraan yang belum sesuai. Dalam faktor alam atau lingkungan, kondisi cuaca yang ekstrim dapat menyebabkan kamera tidak bisa digunakan dan lokasi kamera yang rentan akan pengrusakan oleh oknum tertentu.

\section{Saran}

Dari hasil dan pembahasan serta kesimpulan, peneliti menyarankan bahwa:

1. Sebaiknya peraturan mengenai Tilang secara elektronik dapat diatur secara khusus, yang dimana hal ini dapat diusulkan oleh Direktor Lalu Lintas Polda Metro Jaya kepada Mabes Polri. Sejalan dengan hal tersebut, maka diharapkan agar unit khusus Tilang elektronik dapat dibentuk, serta penambahan kamera berbasis ETLE yang mendukung, dan juga alokasi anggaran yang dapat mendukung kinerja pelaksaanaan Tilang secara elektronik.

2. Sebaiknya dilakukan sosialisasi hukum oleh Direktorat Lalu Lintas Polda Metro Jaya kepada masyarakat mengenai aturan balik nama bukti kepemilikan kendaraan bermotor, penggunaan Tanda Nomor Kendaraan Bermotor, beserta prosedur dalam 
menyelesaikan pelanggaran Tilang elektronik yang tentunya dapat memberi ilmu baru dan kesadaran hukum bagi masyarakat.

\section{DAFTAR PUSTAKA}

Andi Hamzah, J. (2012). Asas-Asas Hukum Pidana di Indonesia \& Perkembangannya, Jakarta. PT. Sofmedia.

Ash-Shofa, B. (2004). Metode Penelitian Hukum, PT Rineka. Cipta Jakarta.

Atmasasmita, R. (2011). Sistem Peradilan Pidana Kontemporer, cet. Ke-2, Jakarta: Kencana.

Henry, C. (1998). Black's Law Dictionary; Seventh Edition. St. Paulmin West Publicing. Co.

Hiariej, E. O. S. (2014). Prinsip-Prinsip Hukum Pidana. Cahaya Atma Pustaka.

Karjadi, M. (2011). kejahatan Pelanggaran dan Kecelakaan. Bogor, Politeia.

Marzuki, P. M. (2013). Penelitian Hukum. Kencana.

Satjipto, R. (2009). Penegakan Hukum suatu tinjauan sosiologis. Yogyakarta: Genta Publising.

Soekanto, S. (2007a). Faktor-faktor yang mempengaruhi penegakan hukum.

Soekanto, S. (2007b). Sosiologi: Suatu Pengantar. PT Raja Grafindo Persada. 